\title{
Családok, barátok, közösségek - a testi, lelki és szociális jóllét kapcsolata városi felnốtt fiatalok körében
}

\section{Bevezetés}

A fiatal felnőttek egészségmagatartása kevéssé vizsgált terület, miközben a fiatal felnőtt korban elterjedt egészségkárosító szokások jelentősen meghatározzák a későbbi egészségi állapotot, az egészségben töltött évek számát és az életkilátásokat. Ez a hatás nem egyirányú, sôt valószínú, hogy a pszichés egészség és az életminőség jelentős hatást gyakorol bizonyos egészségre ártalmas magatartási minták választására.

A fiatal felnőtt korosztály egyre nagyobb részét képezik a serdülőkorból már kinőtt, de társadalmi értelemben felnőtté válni nem tudó (vagy nem akaró) posztadoleszcensek. A posztadoleszcencia (kései fiatalkor) fogalmát a fiatal felnőttek azon csoportjára használjuk, akik a felnőtté válás folyamatának valamely szakaszában vannak, de még nem érték el a szociológiai értelemben vett felnőtt státuszt. Ezek a fiatalok a felnőtt szerep bizonyos szimbólumaival (pl. legális nagykorúság, önálló kereset stb.) már rendelkeznek, de a felnőtt státusz minden elemét (pl. saját család, teljes függetlenedés a szülőktől stb.) még nem birtokolják. (A poszadoleszcenciáról bővebben lásd: Vaskovics 2000: 3-20.)

A felnőtt lakosság körében végzett számos kutatás igazolja a társadalmi integráció fizikai és mentális egészségre gyakorolt pozitív hatását (pl. Busa és társai 2009). Kérdés azonban, hogy ez az összefüggés a fiatal felnőtt korosztályban is kimutatható-e.

\section{A kutatásról}

A Fact Intézet 2010-ben (a KAB-KT-09-0011 azonosítószámú pályázat keretében) komplex felmérést készített a 18-31 éves városi fiatal felnőttek egészségkárosító magatartásformáiról, valamint szubjektív egészségi állapotuk fizikai, mentális és szociális dimenzióiról. (A kutatásról és eredményeiről részletesebben lásd Tistyán és társai 2010.) A kérdőíves vizsgálat a fiatal felnőttek két, kvótás mintavétellel és szúrôkérdésekkel kiválasztott 500-500 fős részmintájára terjedt ki:

1. posztadoleszcens minta (az e részmintába kerülő válaszadók vagy gazdasági aktivitásuk, vagy lakóhelyük, vagy anyagi egzisztenciájuk tekintetében még nem rendelkeznek a felnőtt lét elemeivel);

2. kontroll minta (e részminta tagjai már magukénak tudhatják a felnőtt státusz fent meghatározott elemeit). 
A célcsoportokban az adatfelvétel face-to-face interjúk formájában valósult meg. E cikk a kutatás során összegyújtött adatok másodelemzésével készült.

\section{Szubjektív egészségi állapot, egészségkárosító magatartásformák}

A vizsgált korosztály szubjektív egészségi állapot mutatói jók: a 0-tól 10-ig terjedő skálán 8,07-es átlaggal jellemezték fizikai egészségüket. Az egészségkárosító magatartásformákat tekintve a megkérdezett 18-31 évesek közel egyharmada $(31,2 \%)$ naponta dohányzik, döntő többségük $(81,9 \%)$ viszont csak alkalmilag fogyaszt alkohol. (Lásd az 1. táblázatot.) Az illegális drog használatának életprevalenciája 23,2\%. A 18-31 éves korosztályban mind az alkalmi dohányzás, mind az alkalmi alkoholfogyasztás jellemzően a szórakozáshoz és a társasági élethez kötődik: az alkalmilag dohányzók 82,2\%-a, az alkalmi alkoholfogyasztók 90,2\%-a akkor él e szenvedélyekkel, ha társaságba és / vagy szórakozni megy.

A vizsgált egészségkárosító magatartásformák elterjedtségét tekintve nem mutatkoztak szignifikáns különbségek a két részminta között.

\section{1. táblázat: Egészségkárositó magatartásformák}

\begin{tabular}{|l|r|r|r|}
\hline Dohányzási szokások - gyakoriság & & $31,2 \%$ naponta & $14,6 \%$ alkalmanként \\
\hline $\begin{array}{l}\text { Alkoholfogyasztási szokások - } \\
\text { gyakoriság (elmúlt 30 napban) }\end{array}$ & $1,5 \%$ naponta & $\begin{array}{r}14,3 \% \text { heti } 2-5 \\
\text { alkalommal }\end{array}$ & $\begin{array}{r}81,9 \% \text { heti } \\
\text { max.1 alkalommal }\end{array}$ \\
\hline $\begin{array}{l}\text { Illegális drog használata - } \\
\text { életprevalencia }\end{array}$ & & & $23,2 \%$ próbálta már \\
\hline
\end{tabular}

A kutatásban részt vevő városi fiatal felnőttek több mint négyötöde $(87,2 \%$-a) boldognak minősítette magát. (1. ábra) E területen szignifikáns az eltérés a kutatás két részmintája között: a kontroll minta tagjai nagyobb arányban (34,8\%) vallották magukat boldognak és az élet dolgai iránt érdeklődőnek, mint a posztadoleszcensek $(24,3 \%)$. Figyelemre méltó adat, hogy a megkérdezettek 12-13\%-a valamilyen mértékben boldogtalan, ami meglehetősen magas aránynak tekinthetô egy ilyen fiatal korcsoport esetében.

A személyes jóllét szubjektív észlelésének méréséhez a Robert A. Cummins által kifejlesztett „Personal Wellbeing” skálákat használtuk (az egyes dimenziókat lásd a 2. ábrán). A skála értékeinek interpretálása mögött az az előfeltevés áll, hogy ,az élettel való elégedettségnek" van egy általános, a skálákat tekintve elég magas emberi alapszintje. Tehát az a „,normális” állapot, ha az ember elégedett, boldog. Pszichésen ez szükséges ugyanis ahhoz, hogy mindennapi életét élni tudja valaki. Ennek a „boldogsági alapszintnek” a fenntartására - egyféle „homeosztatikus kontrollnak" a segítségével - mindent meg is teszünk, akár úgy is, hogy az objektíve rosszabb körülményeket nem is észleljük vagy nem vesszük tudomásul (Cummins 2000: 55-72.). Cummins szerint ez az emberi alapszint a szubjektív jólétet mérő 
1. ábra: Miként jellemezné magát általában?

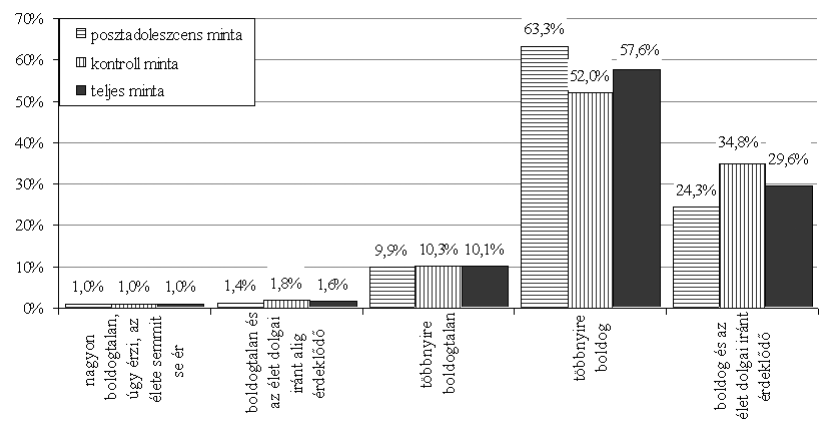

skálák maximumának 60-80\%-a körül van, másutt azonban úgy vélekedett, hogy a „nyugati társadalmakban” a skálák értékeinek ,normativ range”-e 70-80, míg a „,nem nyugati társadalmakban” ezek az értékek 10\%-kal alacsonyabbak (Cummins 2005). Kutatásunkban a 70-es skálaértéket tekintettük a fejlett társadalmak szintjének, és a 60-as értéket az emberi alapszintnek.

A 18-31 éves városi fiatalok esetében az egészség, az emberi kapcsolatok és a közösségi kötődések dimenzióiban közelítik vagy haladják meg a mért adatok a fejlett társadalmakra jellemző szintet. Két olyan terület is van azonban (az életszínvonal és a biztos jövő), ahol a regisztrált értékek nem érik el az emberi alapszint határát sem. A * jelzésú területeken a két részminta adatai közötti különbség statisztikailag szignifikáns. Így az emberi kapcsolatok, a hitélet és az életben elért eredmények dimenziókban a kontroll minta tagjai lényegesen jobban ,teljesítenek”, mint a posztadoleszcensek.

\section{2. ábra: Cummins-féle „Personal Wellbeing” (Személyes jóllét) skála}

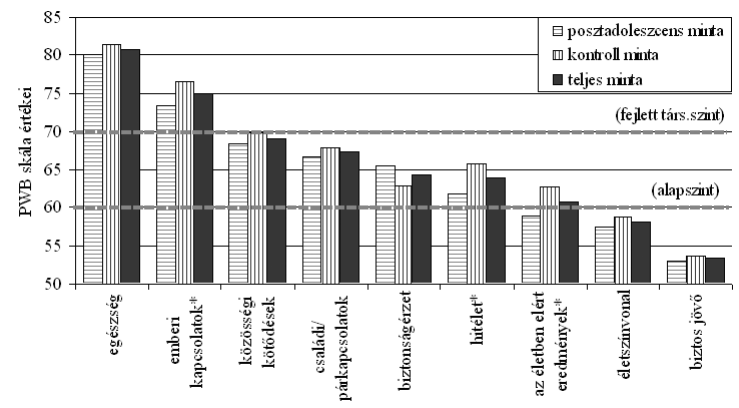

A megkérdezett fiatalok 90,2\%-ának van legalább egy igaz barátja: harmaduknak egy, több mint felüknek kettő is. Döntő többségük, 79-88\%-uk szükség esetén családja és barátai részéről is számíthat segítségre, társas támogatásra. A posztadoleszcens fiatalok esetében a család és a rokonság részérôl történő támogatás is magasabb arányú, mint a kontroll mintában, a különbség 8-9\%. (2. táblázat). 
A vizsgált korosztály számára a közösségi kapcsolatok jellemzően a baráti kötődéseket jelentik: négyötödük $(79,5 \%)$ számolt be olyan állandó társaságról, amelynek tagjaival rendszeresen találkozik, miközben formális szervezetben negyedük $(25,8 \%)$ rendelkezik tagsággal. A kontroll mintába tartozók körében a társadalmi szervezetek munkájában való aktív részvétel magasabb gyakorisággal fordul elő.

2. táblázat: Szociális egészség, társas kapcsolatok

\begin{tabular}{|c|c|c|c|}
\hline Igaz barátja & & $32,9 \%$ egy van & $57,3 \%$ több van \\
\hline \multirow{4}{*}{ Van igazán közel álló személy } & & & a baráti körében $88,0 \%$ \\
\hline & $\begin{array}{r}\text { a családjában } \\
79,3 \%\end{array}$ & $\begin{array}{r}\text { (posztadoleszcens } \\
\text { minta: } 83,2 \% \text { ) }\end{array}$ & $\begin{array}{r}\text { (kontroll } \\
\text { minta: } 75,4 \%)\end{array}$ \\
\hline & & & a környezetében 49,7\% \\
\hline & $\begin{array}{r}\text { a rokonságában } \\
42,6 \%\end{array}$ & $\begin{array}{r}\text { (posztadoleszcens } \\
\text { minta: } 47,0 \%)\end{array}$ & $\begin{array}{r}\text { (kontroll } \\
\text { minta: } 38,2 \%)\end{array}$ \\
\hline $\begin{array}{l}\text { Társadalmi } \\
\text { szervezet tagja }\end{array}$ & $25,8 \%$ & $\begin{array}{r}\text { (posztadoleszcens } \\
\text { minta: } 22,3 \% \text { ) }\end{array}$ & $\begin{array}{r}\text { (kontroll } \\
\text { minta: } 29,6 \%)\end{array}$ \\
\hline $\begin{array}{l}\text { Van olyan állandó társaság, } \\
\text { akikkel rendszeresen találkozik }\end{array}$ & & & $79,5 \%$ \\
\hline
\end{tabular}

Megjegyzés: A táblázatban a két mintára vonatkozó adatokat csak a statisztikailag szignifikáns különbségek esetében tüntettükfel.

A kutatás adatainak másodelemzése során a társadalmi integráció szempontjából két csoportot különítettünk el. Erôs társas támogatással rendelkezóknek tekintettük azokat, akik mind a baráti körük, mind a családjuk részéról számíthatnak segítségre. E kategória a teljes minta 70,9\%-át jelenti. A másik kategóriába sorolt fiatalok esetében a társas támogatás intenzitása gyengébb (vagy csak a család, vagy csak a barátok részéről tapasztalható), illetve hiányzik. Ők alkotják a minta 29,1\%-át.

A társadalmi integrációt tekintve a posztadoleszcens fiatalok helyzete kedvezőbb: háromnegyedük $(74,4 \%)$ erôs társas támogatásról számolhatott be, míg a kontroll mintában a válaszadók kétharmada $(67,4 \%)$ tartozik az erôs társadalmi integrációval jellemzett csoportba.

\section{A társadalmi integráció és az egészség összefüggései}

Az intenzív társas támogatás a fiatal felnőttek körében is pozitív kapcsolatot mutat az egészségi állapot önértékelésével, azaz az erősebb társadalmi integrációval rendelkezők szubjektív egészségátlaga szignifikánsan magasabb, mint a gyengébb vagy hiányzó társadalmi beágyazottsággal jellemzett csoporté. Ez összefüggés mind a posztadoleszcens, mind a kontroll mintán belül megmutatkozott. (A pontos adatokat lásd a 3. ábrán.) 
3. ábra: Szubjektív egészségi állapot - társas kapcsolatok

(Egészségével való elégedettség 0-10 átlagok)

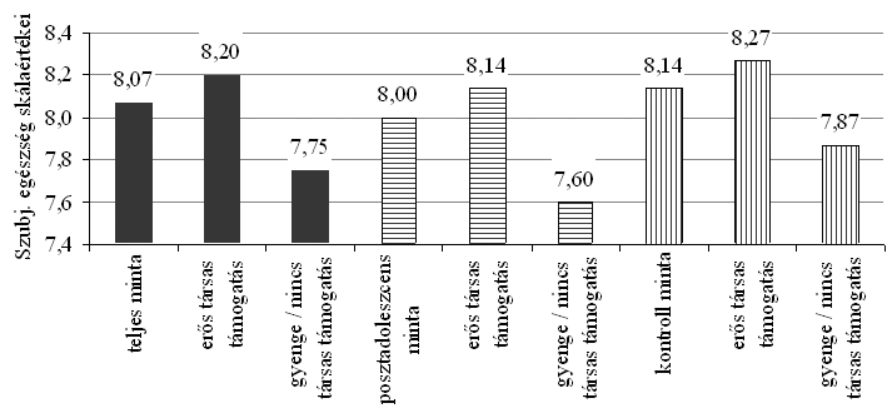

A társas támogatás intenzitásával összefüggésben a vizsgált egészségkárosító magatartásformák elterjedtsége is számottevő (8-12\%-os) különbségeket mutat. A rendszeres (napi) dohányzás, a rendszeres (minimum heti két alkalommal történő) alkoholfogyasztás és az illegális droghasználat életprevalenciája is magasabb a gyenge vagy hiányzó társas támogatással jellemezhető fiatalok körében, mint az erős társadalmi integrációval rendelkezők esetében.

Ugyanez a kapcsolat szignifikáns eltéréseket rajzolt ki a posztadoleszcens fiatalok részmintáján belül, sőt a különbségek még jelentősebbek (12-17\% közöttiek). Különösen a napi dohányzás terén tapasztalt eltérés markáns: 46,1, illetve 28,8\%.

3. táblázat: Egészségkárosító magatartásformák - társas kapcsolatok

\begin{tabular}{|r|r|r|r|} 
& & $\begin{array}{r}\text { Erôs társas } \\
\text { támogatás }\end{array}$ & $\begin{array}{r}\text { Gyenge / nincs } \\
\text { társas támogatás }\end{array}$ \\
\hline $\begin{array}{r}\text { Naponta } \\
\text { dohányzik }\end{array}$ & posztadoleszcens minta $(33,2 \%)$ & $27,6 \%$ & $39,9 \%$ \\
\hline Alkoholfogyasztás min. & teljes minta $(11,4 \%)$ & $28,8 \%$ & $46,1 \%$ \\
heti két alkalommal & posztadoleszcens minta $(11,4 \%)$ & $8,6 \%$ & $18,2 \%$ \\
Használt már & teljes minta $(23,2 \%)$ & $21,0 \%$ & $20,3 \%$ \\
illegális drogot & posztadoleszcens minta $(24,0 \%)$ & $21,0 \%$ & $28,5 \%$ \\
\hline
\end{tabular}

Megjegyzés: A táblázatban csak a statisztikailag szignifikáns különbségeket tüntettük fel. A kontroll mintán belüli különbségek statisztikailag nem szignifikánsak.

A fizikai egészséghez hasonlóan az erősebb társas támogatás kedvezóbb boldogságönminősítéssel jár együtt a posztadoleszcens és a kontroll mintában egyaránt. A magukat boldognak vagy többnyire boldognak tartók részaránya 90\% feletti azon fiatalok körében, akik szükség esetén mind családjuk, mind barátaik részéról számíthatnak segítségre. A gyengébb társadalmi integrációról beszámolók körében a magukat valamilyen mértékben boldognak minősítők aránya ennél alacsonyabb, 73-75\%. 
4. ábra: Boldogság - társas kapcsolatok

(Boldogok vagy többnyire boldogok aránya)



A személyes jóllét és a társas támogatás összefüggéseit tekintve jól látható (5. ábra), hogy az erősebb társadalmi integráció a személyes jóllét dimenzióiban mért magasabb értékekkel jár együtt. Az erôs társas támogatással rendelkezők körében a skála kilenc dimenziója közül négyben a mért érték meghaladja (egészség, emberi kapcsolatok, közösségi kapcsolatok) vagy megközelíti (családi kapcsolatok / partnerkapcsolat) a fejlett társadalmakat jellemző szintet. Ugyanez a társadalmi integráció alacsonyabb fokán állók esetében csak két területtel kapcsolatban mondható el (egészség, emberi kapcsolatok).

A társas támogatás mentén megragadható különbségeket jól mutatja, hogy míg az erôs társas támogatást élvezők csoportjában a vizsgált kilenc dimenzióból kettő esetében található a mért adat az emberi alapszint közelében, illetve került az alá (életszínvonal, biztos jövő), addig a társadalmi integráció szempontjából kedvezőtlen(ebb) helyzetben lévők csoportjában a kilenc dimenzió között mindössze négy olyan van, ahol a regisztrált érték nem az emberi alapszint határán, vagy az alatt „mozog” (egészség, emberi kapcsolatok, közösségi kapcsolatok, családi kapcsolatok / partnerkapcsolat).

\section{5. ábra: „Personal Wellbeing” (Személyes jóllét) - társas kapcsolatok}

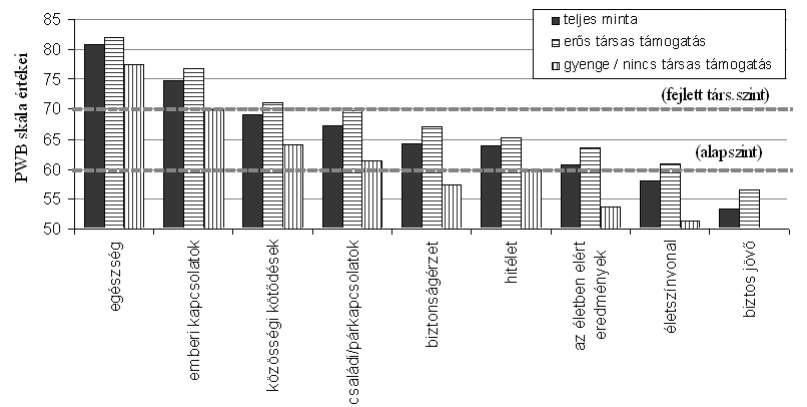


A fentiekben ismertetett tendencia a posztadoleszcens és a kontroll részmintán belül is megmutatkozik, vagyis azok körében érik el vagy haladják meg nagyobb számban a regisztrált adatok a fejlett társadalmakat jellemző szintet, ahol erősebb a társas támogatás. (A pontos adatokat lásd a 4. táblázatban.) A skála másik végpontján is ez az összefüggés érvényesül: a társadalmi integráció szempontjából kedvező helyzetben lévő válaszadók esetében egy-két dimenzióban maradnak a mért értékek az emberi alapszint alatt, míg a gyengébb társas támogatásról beszámoló fiatalok esetében három-négy területen. (A két részmintában a társadalmi integráció mentén megmutatkozó különbségek statisztikailag szignifikánsak.)

\section{4. táblázat: „Personal Wellbeing” (Személyes jóllét) - társas kapcsolatok (PWB skála értékei)}

\begin{tabular}{|c|c|c|c|c|c|c|c|c|c|}
\hline & 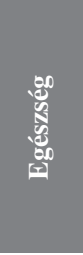 & 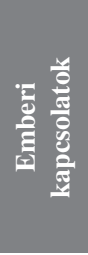 & 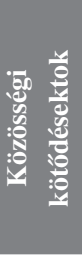 & 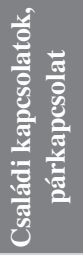 & 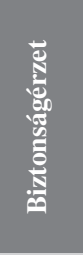 & 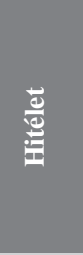 & 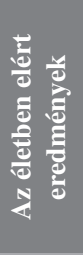 & 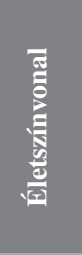 & $\begin{array}{l}i e \\
: 0 \\
\frac{8}{8} \\
\frac{8}{20}\end{array}$ \\
\hline Posztadoleszcens minta & 80,04 & 73,38 & 68,41 & 66,63 & 65,53 & 61,83 & 58,86 & 57,47 & 53,06 \\
\hline Erős társas támogatás & 81,42 & 74,92 & 69,89 & 68,30 & 67,34 & 63,70 & 61,61 & 59,81 & 55,19 \\
\hline $\begin{array}{r}\text { Gyenge / nincs társas } \\
\text { támogatás }\end{array}$ & 76,02 & 68,91 & 64,05 & 61,80 & 60,24 & 55,86 & 50,86 & 50,70 & 46,88 \\
\hline Kontroll minta & 81,40 & 76,47 & 69,86 & 67,99 & 62,92 & 65,65 & 62,66 & 58,76 & 53,63 \\
\hline Erôs társas támogatás & 82,73 & 79,23 & 72,75 & 71,37 & 66,73 & 67,08 & 65,95 & 62,17 & 57,89 \\
\hline $\begin{array}{r}\text { Gyenge / nincs társas } \\
\text { támogatás }\end{array}$ & 78,65 & 70,68 & 63,81 & 60,99 & 54,97 & 62,67 & 55,78 & 51,67 & 44,75 \\
\hline
\end{tabular}

Jelmagyarázat: fejlett társ. szintje feletti érték alapszint és fejlett társ. szintje közötti érték alapszint alatti érték

A kutatás során megvizsgáltuk, hogy a fiatal felnőttek hogyan reagálnak, milyen problémakezelési alternatívákat választanak, ha „maguk alatt vannak”. A kérdőívben felsorolt 19 lehetôség közül az öt leggyakoribb válasz (1) a zenehallgatás, (2) a barátokkal való beszélgetés (e két válaszalternatívát a megkérdezettek háromnegyede jelölte meg), (3) az internetezés, számítógépezés, (4) a tévé-, DVD-, videónézés, valamint (5) a családdal, partnerrel foglalkozás volt (utóbbiak említési gyakorisága 63-67\%). A barátokkal, családdal, partnerrel való foglalkozás gyakoribb választásnak bizonyult a társas támogatás alapján kedvezốbb helyzetben lévő fiatalok körében, hiszen e csoportot több és erősebb kapcsolat füzi ezekhez a személyekhez, mint a gyengébb társadalmi integrációval jellemzett társaikat. (5. táblázat)

A 19 problémakezelési módszer között kettő olyan szerepelt, az evés és a valamilyen szerrel (dohánnyal, alkohollal, kábítószerrel, nyugtatóval) való ellazulás, amely negatív hatással van vagy lehet az egészségre. E két problémakezelési mó- 
dot nagyobb gyakorisággal választották mind a posztadoleszcens, mind a kontroll mintában azok a fiatalok, akik társas támogatottsága gyengébb vagy hiányzik. Az evés mint problémakezelési alternatíva esetén 10-12\%-os, a valamilyen szerrel való ellazulás esetén 8-13\%-os különbségeket regisztráltunk.

\section{5. táblázat: Problémakezelési alternatívák - társas kapcsolatok (rangsorok, említési gyakoriságok)}

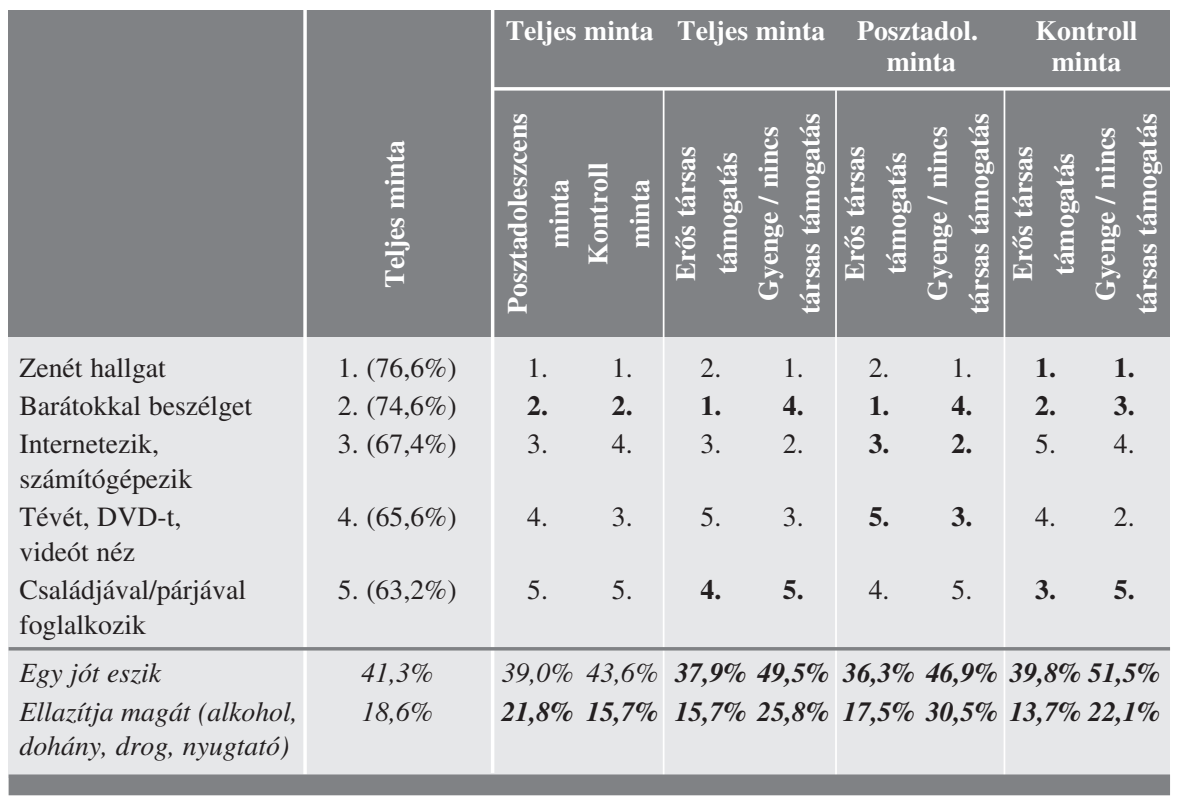

Megjegyzés: A táblázatban a vastagon kiemelt számok a statisztikailag szignifikáns különbségeket jelölik.

\section{A legfontosabb megállapítások összefoglalása}

A kutatás célcsoportját jelentő 18-31 éves városi fiatal felnőttek szubjektív egészségi állapot-értékelése pozitív, és többnyire boldognak érzik magukat. Döntő többségük (71\%) szükség esetén családja és barátai részérôl is számíthat segítségre, támogatásra, azaz kellő társas támogatással rendelkeznek. A személyes jóllét különbözô tényezőit tekintve az egészség, az emberi kapcsolatok és a közösségi kötödések dimenziói mutatnak kedvező értékeket, számos területen azonban nagyon alacsony, néhány dimenzióban pedig az emberi alapszintet el nem érô adatokat regisztráltunk.

A felnőtt populációban végzett vizsgálatokhoz hasonlóan a fiatal felnőtteknél is pozitív kapcsolatot mutat a társadalmi integráció intenzitása és az önminősített egészségi állapot. Ez az összefüggés mind a posztadoleszcens, mind a kontroll mintán belül érvényesült. Az erősebb társadalmi támogatás jótékony hatást gyakorol a 
fiatal felnőttek fizikai és lelki egészségére, azaz ezek a fiatalok jobbnak ítélik szubjektív egészségi állapotukat, kisebb arányban élnek egészségkárosító magatartásformákkal, boldogabbnak tartják magukat, kevésbé rossz személyes jóllét-adatokkal jellemezhetőek, és kisebb valószínúséggel választanak egészségkárosító problémakezelési alternatívákat, mint a társadalmi integráció alacsonyabb fokán álló társaik. Ez utóbb csoportba tartozik azonban a 18-31 éves városi fiatal felnőttek több mint egynegyede (29\%-a).

\section{Hivatkozott irodalom}

Busa Csilla-Füzesi Zsuzsanna-KeszTyüs MáRK-Tistyán LÁszló (2009): A gazdasági- és társadalmi válság hatása az egészségi állapotra és az egészséggel kapcsolatos döntésekre - Egészségrecesszió kutatás. Kutatási zárójelentés. Pécs, Fact Alkalmazott Társadalomtudományi Kutatások Intézete. Internet: http://fact.hu/hireink/egeszsegrecesszio-kutatas-2009

Cummins, Robert A. (2000): Objective and subjective quality of life: an interactive model. Social Indicators Research 52 (1), 55-72.

Cummins, Robert A. (2005): Personal Wellbeing Index - School Children. Melbourne, Deakin University. Internet: http://www.deakin.edu.au/research/ acqol/instruments/wellbeing-index/pwi-sc-english.pdf

TISTYÁN LÁsZLÓ-KESZTYÜs MÁRK-FÜZESI ZsuZSANNA (2010): Egészségkárosító magatartásformák a fiatal felnöttek két csoportjában. Kutatási zárójelentés. Pécs, Fact Alkalmazott Társadalomtudományi Kutatások Intézete. Internet: http:/fact.hu/hireink/egeszsegkarosito-magatartasformak-vizsgalata

VAskovics LÁszló (2000): A posztadoleszcencia szociológiai elmélete. Szociológiai Szemle 10 (4), 3-20. 